\section{'Stop me before I kill again': why Philip Morris International needs governments' help to quit smoking, and why governments need more pressure to do so}

\author{
Ruth E Malone
}

As reported elsewhere in this issue and in numerous media outlets, Philip Morris International (PMI) recently published advertisements in several UK newspapers claiming its New Year's Resolution was 'We're trying to give up cigarettes'. Numerous observers noted that there was no specific plan or date attached to this goal, the company continues aggressively promoting cigarettes in low-income and middle-income countries, and previous similar makeover efforts undertaken by the company have been a smokescreen. Lending credence to sceptics' responses, the company is currently 'upgrading' a UK version of its top-selling Marlboro cigarettes at the same time. ${ }^{2}$

The company has long been urged to just stop promoting and/or selling cigarettes. For many years, public health advocates have attended shareholder meetings and called on the company to stop. The most recent call, however, came in an open letter to the company endorsed by more than 100 organisations from around the world. ${ }^{34}$ Such efforts are typically met with the company's earnest explanation that even if they did, other companies would step into the breach, so obviously there is no point in doing so.

And in one sense, that is completely true. The fact is that PMI can't just stop: its shareholders are too addicted to the profits generated by cigarette sales. If the Chief Executive Officer announced tomorrow that PMI would end sales of combustible cigarettes, shareholders would undoubtedly demand that Directors replace him. As even some public health advocates have argued, it is naïve to think otherwise. But that is not the point. If you are genuinely trying to do the right thing, you do it regardless of what anyone else is doing, and you accept the consequences. It is clear PMI's leadership is not quite ready for that, so the claim that

Correspondence to Professor Ruth E Malone, Social and Behavioral Sciences, University of California, San Francisco CA94118, USA; ruth.malone@ucsf.edu it really wants to quit must be taken with more than a grain of salt.

So what are we to make of the claim that PMI wants to quit? First, it is not surprising that PMI would pick the UK as a place to advertise its wish to quit smoking. The UK has been more friendly than many other jurisdictions to embracing a new prodtion' and seems more willing to encourage vaping as a smoking replacement. PMI would undoubtedly like to sell more of its new 'potentially less risky' products there, like its heat-not-burn IQOS, while giving the appearance of becoming a more responsible company after decades of pariah status. Interestingly, PMI's UK initiative website, touted as part of its ad campaign, is not even accessible to those from other countries, possibly because it is apparently focused on what it can learn about building a market for these 'potentially less risky alternatives'.

But a market only focused on persuading a shrinking pool of addicted smokers in the UK to switch to IQOS is not a sustainable long-term business strategy. PMI needs new consumers. So we should all be clear about one thing: 'giving up cigarettes' for PMI does not mean the company wants people to quit using its addiction sticks. It means they want to get people hooked on a different type of addiction stick. And that has to include new users.

Those who believe fervently that markets will solve all ills take heart at these developments, anticipating a time when users of combustible cigarettes will voluntarily and happily switch to the multiple other 'harm reduction' products not yet demonstrated to be safe for long-term use, while still being offered the 'choice' of the most deadly and satisfying forms of nicotine products. But if the new offerings are so good (and perhaps in relative terms they will prove to be so), then why continue to offer the most deadly forms of these products at all? Why not develop a real plan to phase these most deadly products off the uct-focused notion of 'tobacco harm reduc- market? Why not actually make PMI quit smoking?

For many years, proposing such an idea was anathema to public health advocates leery of being labelled prohibitionists and nannies, although brave souls proposed it in various forms. ${ }^{5-7}$ But now that some countries are seriously discussing how to achieve a tobacco 'endgame', ${ }^{8}$ the idea no longer seems so impossible." The 'third rail' of phasing out cigarettes is no longer untouchable. And this is undoubtedly why PMI decided it was the moment to set up its 'Foundation for a Smoke-free World', ${ }^{10}$ with a pledge of US\$1 billion and an agenda serving its business needs. Much better to spend years and money studying alternative distraction sticks while convincing the gormless that you are hastening to be part of the solution (no, really, really, really, this time for sure) than to face the prospect of actually ending your cigarette sales.

Only governments can make them do it. Until governments act, many more people will get sick and die from cigarettes. And this is where things do get dicey. Much as they would hate to admit it, governments are addicted to tobacco too, in the form of taxes. Even though countries lose money overall when the health, environmental and other externalised costs of cigarette use are factored in, few governments have been savvy enough to make long-term plans for replacing the shrinking revenue from cigarettes. Some lawmakers are also addicted to tobacco company campaign contributions, and thus reluctant to bite the hand that feeds them.

Only a civil society movement laser-focused on ending the cigarette epidemic can make governments finally phase out sales of the cigarette, the single most deadly consumer product ever made. Philip Morris's advertisement - a virtual plea to 'stop me before I kill again' — ought to be taken seriously. There is no reason why a plan to phase out cigarette sales cannot be developed and pursued now. In some countries like the UK, such a plan may involve other products purported (if not fully demonstrated) to be less harmful to health. In others, it may mean raising taxes even higher and increasing on a regular basis the age to purchase. It won't be easy. But it is time. Not a single additional study is needed to demonstrate that cigarettes kill more people, more reliably, than any other product. Let's do this.

\section{Competing interests None declared.}

Provenance and peer review Not commissioned; internally peer reviewed.

(C) Article author(s) (or their employer(s) unless otherwise stated in the text of the article) 2018. All 


\section{Editorial}

rights reserved. No commercial use is permitted unless otherwise expressly granted.

\section{A) Check for updates}

To cite Malone RE. Tob Control 2018;27:121-122.

Tob Control 2018:27:121-122.

doi:10.1136/tobaccocontrol-2018-054294

\section{REFERENCES}

1 Rahhal N. Daily Mail. Philip Morris vows to give up smoking for the new year: Tobacco giant plans to stop selling cigarettes as they turn to trendy vaping.
$2018 \mathrm{http}: / /$ www.dailymail.co.uk/health/article5233401/Philip-Morris-trying-cigarettes-2018html\# ixzz55zhC6dha

2 Talking Retail.com. Philip Morris updates Marlboro Touch. 2018 https://www.talkingretail.com/productsnews/tobacco/philip-morris-updates-marlboro-touch02-07-2015/

3 Action on Smoking and Health. 95 Health groups to Philip Morris International: Stop selling cigarettes. 2017 https://www.prnewswire.com/news-releases/ 95-health-groups-to-philip-morris-internationalstop-selling-cigarettes-300519752.html

4 Action on Smoking and Health. Open letter to PMI from 123 organizations. 2017 https://ash.org/openletter-to-pmi-from-95-orgs/
5 Hall W, West R. Thinking about the unthinkable: a de facto prohibition on smoked tobacco products. Addiction 2008;103:873-4.

6 Daynard RA. Doing the unthinkable (and saving millions of lives). Tob Control 2009;18:2-3.

7 Proctor RN. Why ban the sale of cigarettes? The case for abolition. Tob Control 2013;22:i27-i30.

8 Malone RE. The Race to a Tobacco Endgame. Tob Control 2016;25:607-8.

9 Hefler M. The changing nicotine products landscape: time to outlaw sales of combustible tobacco products? Tob Control 2018;27:1-2.

10 Malone RE, Chapman S, Gupta PC, et al. A "Frank Statement" for the 21st Century? Tob Control 2017;26:611-2. 